\title{
PERBANDINGAN METODE DYNAMIC CELL SPREADING (DCS) DAN SPREAD SPECTRUM PADA STEGANOGRAFI BERBASIS APLIKASI WEB
}

\author{
${ }^{1}$ Wamiliana, ${ }^{2}$ Astria Hijriani, dan ${ }^{2}$ Pita Utari Ningtyas \\ ${ }^{1}$ Jurusan Matematika FMIPA Unila \\ ${ }^{2}$ Jurusan Ilmu Komputer FMIPA Unila
}

\begin{abstract}
The security is the most important thing in sending a secret message and there are many ways to send a message safely, one of those is steganography. In this research we will compare Dynamic Cell Spreading (DCS) and Spread Spectrum method based on web application using image as the media and hide the secret message. The file format used are (.jpg) as input cover,(.png) as output stegoimage, and (.txt) as data that can be inserted. Doing some test to manipulate brightness, contrast, and cropping the results show that Spread Spectrum method better than Dynamic Cell Spreading method. The Spread Spectrum method mostly returns the message in the brightness and contrast manipulation. Cropping stegoimage on the right area or bottom image has less risk of losing data depend on the cropping scale and image resolution.
\end{abstract}

Key words : Steganography, Spread Spectrum, Dynamic Cell Spreading

\section{Pendahuluan}

Keamanan dan kerahasiaan merupakan aspek penting dalam komunikasi data maupun informasi. Kerahasiaan merupakan suatu hal yang dibutuhkan ketika menginginkan agar hal yang dirahasiakan tidak diketahui oleh orang lain namun upaya merahasiakan sesuatu dengan sebaik mungkin tetap saja memiliki celah yang diketahui oleh orang lain untuk dapat mencuri atau mengetahui hal yang dirahasiakan tersebut. Steganografi merupakan seni untuk menyembunyikan pesan rahasia kedalam pesan lainnya sedemikian rupa sehingga membuat orang lain tidak menyadari adanya sesuatu di dalam pesan tersebut. Kata Steganography berasal dari bahasa Yunani, yaitu gabungan dari kata steganos (tersembunyi atau terselubung) dan graphein (tulisan atau menulis), sehingga makna Steganography kurang lebih bisa diartikan sebagai menulis tulisan yang tersembunyi[1]. Steganografi memiliki macam-macam metode seperti metode Dynamic Cell Spreading (DCS) merupakan teknik penyembunyian yang unik dan teknik penyisipan yang lebih terstruktur dalam menerapkan konsep steganografi [2]. Sedangkan metode Spread Spectrum memenuhi sebagian besar spesifikasi terutama kokoh terhadap serangan analisis statistik, karena informasi yang disembunyikan disebarkan dalam seluruh gambar tanpa mengganti properti statistik dari gambar yang disisipi informasi rahasia.[3]. Pada penelitian ini akan dibandingkan metode Spread Spectrum dan metode Dynamic Cell Spreading(DCS) dengan pesan yang disisipkan dalam bentuk file (*.txt), kemudian file (*.txt) akan disisipkan kedalam media penampung (cover image) yang berupa gambar (*.jpg/.jpeg) sehingga menghasilkan output (stegoimage) berupa gambar (*.png) yang didalamnya berupa isi pesan.

\section{Metode}

Penelitian ini menggunakan metode pengembangan sistem waterfall [4] yang terdapat beberapa tahapan yaitu perencanaan sistem, analisis kebutuhan, desain, implementasi, testing, dan pembuatan laporan. Tahapan penelitian ditunjukkan pada Gambar 1. 


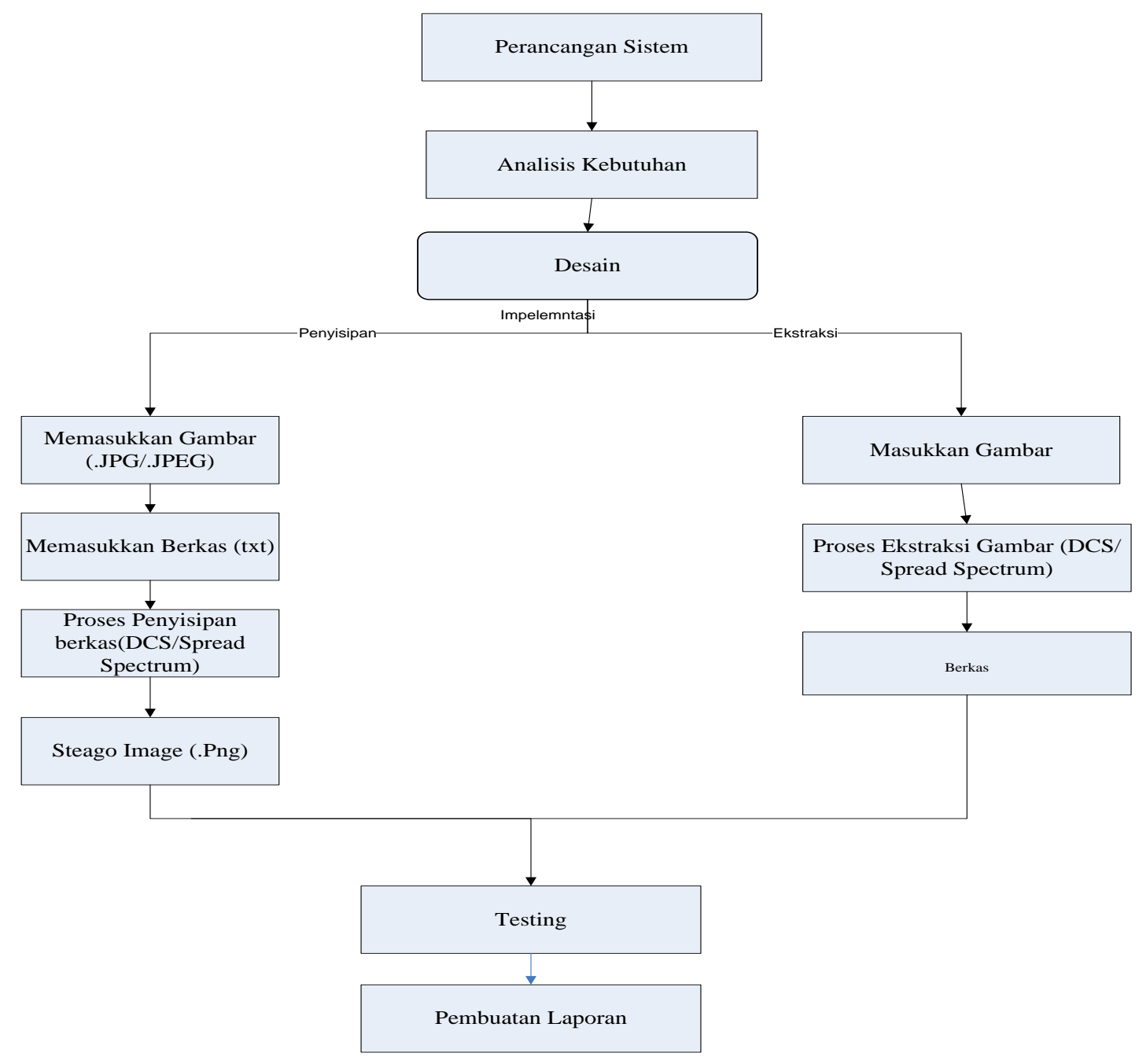

\section{Hasil dan pembahasan}

Pada penelitian ini telah disiapkan pesan yang akan digunakan dalam percobaan ini, yang pesan tersebut berisikan "The Quick Brown Fox Jumps Over the Lazy Dog,.;'[M<>?:" $\{\mid=-$ - $)($ (*\&^\%\$\#@! ’1234567890”.

\section{a. Pengujian perubahan brightness dan contrast}

Penilitian menggunakan 5 file gambar berbeda-beda dengan format(jpg) sebagai media penampung dengan perbedaan ukuran disetiap file gambarnya. Pengujian ini dilakukan dengan cara memanipulasi stegoimage dengan perubahan brightness dan contrast. Interval perubahan brightness dan contrast yaitu $-150,-120,-90,-60,-30,30,60,90,120,150.5$ file gambar (.jpg) disajikan pada Tabel 1. 
Tabel 1. 5 File Gambar (.jpg)

\begin{tabular}{|c|c|c|c|c|}
\hline $\begin{array}{c}\text { No } \\
\text { Gambar }\end{array}$ & Gambar (.jpg) & Ukuran (cm) & Ukuran (pixel) & $\begin{array}{c}\text { Ukuran } \\
(\mathrm{kb})\end{array}$ \\
\hline 1 & & $9,07 \times 6,91$ & $257 \times 196$ & 3,38 \\
\hline 2 & & $13,23 \times 8,55$ & $500 \times 323$ & 58,5 \\
\hline 3 & & $2,96 \times 1,85$ & $350 \times 218$ & 25,3 \\
\hline 4 & & $16,23 \times 10,8$ & $460 \times 306$ & 18,1 \\
\hline 5 & & $1778 \times 873,76$ & $700 \times 344$ & 78,2 \\
\hline
\end{tabular}

Sebelum melakukan manipulasi file citra gambar, telah dilakukan penyisipan berkas terhadap5 gambar tersebut dengan "The Quick Brown Fox JumpsOver the Lazy Dog,.;'|||<>?:" $\mid\} \mid=-$ - $)(* \& \wedge \% \$ \# @$ ! '1234567890”.

Tabel 2. Pengujian 5 File Gambar Dengan Berkas (.txt)

\begin{tabular}{|c|c|c|c|}
\hline $\begin{array}{c}\text { No } \\
\text { Gambar }\end{array}$ & Gambar (.jpg) & $\begin{array}{c}\text { Stegoimage (.png) } \\
\text { Spread Spectrum }\end{array}$ & $\begin{array}{c}\text { Stegoimage (.png) } \\
\text { DCS }\end{array}$ \\
\hline 1 & & & \\
& $3,38 \mathrm{~kb}$ & $22,3 \mathrm{~kb}$ & $22,3 \mathrm{~kb}$ \\
\hline 2 & & & \\
& $58,5 \mathrm{~kb}$ & $258 \mathrm{~kb}$ & $25 \mathrm{~kb}$ \\
\hline
\end{tabular}


(C2017 Ilmu Komputer Unila Publishing Network all right reserve

\begin{tabular}{|c|c|c|c|}
\hline $\begin{array}{c}\text { No } \\
\text { Gambar }\end{array}$ & Gambar (.jpg) & $\begin{array}{l}\text { Stegoimage (.png) } \\
\text { Spread Spectrum }\end{array}$ & $\begin{array}{c}\text { Stegoimage (.png) } \\
\text { DCS }\end{array}$ \\
\hline 3 & $25,3 \mathrm{~kb}$ & $64,8 \mathrm{~kb}$ & $65 \mathrm{~kb}$ \\
\hline 4 & $18,1 \mathrm{~kb}$ & $122 \mathrm{~kb}$ & $121 \mathrm{~kb}$ \\
\hline 5 & $\begin{array}{l}\text { A } \\
78,2 \mathrm{~kb}\end{array}$ & $\begin{array}{r}4.4 \\
358 \mathrm{~kb}\end{array}$ & 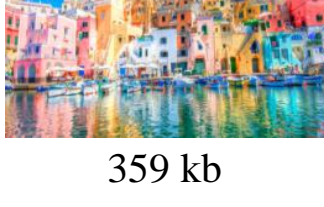 \\
\hline
\end{tabular}

\subsubsection{Pengujian Perubahan Brightness}

Pada percobaan ini dilakukan dengan cara melakukan perubahan brightness dengan interval $150,-120,-90,-60,-30,30,60,90,120,150$ di masing-masing citra stegoimage. Contoh manipulasi stegoimage dengan perubahan brightness disajikan pada Tabel 3.

Tabel 3. Perubahan Brightness

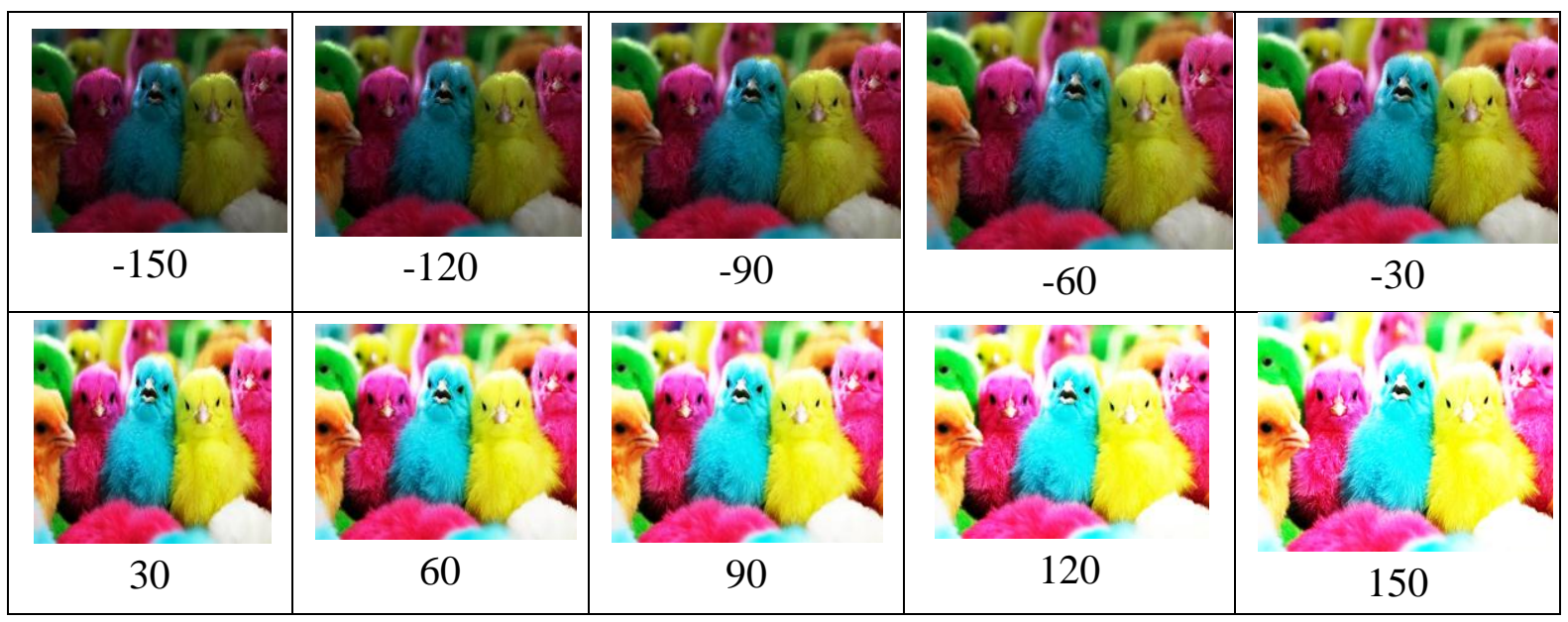

Setelah dilakukan perubahan brightness pada seluruh stegoimage dengan menggunakan metode Spread Spectrum dan Dynamic Cell Spreading (DCS), gambar yang tidak tahan terhadap perubahan brightness. Hasil pengujian dengan perubahan brightness dapat dilihat pada Tabel 4.1 dan Tabel 4.2 
(C2017 Ilmu Komputer Unila Publishing Network all right reserve

Tabel 4.1 Ulasan Pengujian Perubahan Brightness DCS

\begin{tabular}{|c|c|c|c|c|c|c|c|c|c|c|}
\hline \multirow{2}{*}{ No Gambar } & \multicolumn{7}{|c|}{ Perubahan Brightness } \\
\cline { 2 - 12 } & -150 & -120 & -90 & -60 & -30 & 30 & 60 & 90 & 120 & 150 \\
\hline Gambar 1 & & & & & & & & & & \\
\hline Gambar 2 & & & & & & & & & & \\
\hline Gambar 3 & & & & & & & & & & \\
\hline Gambar 4 & & & & & & & & & & \\
\hline Gambar 5 & & & & & & & & & & \\
\hline \hline
\end{tabular}

berkas tidak kembali

berkas kembali namun tidak lengkap

Tabel 4.2. Ulasan Pengujian Perubahan Brightness Spread Spectrum

\begin{tabular}{|c|c|c|c|c|c|c|c|c|c|c|}
\hline \multirow{2}{*}{ No Gambar } & \multicolumn{7}{|c|}{ Perubahan Brightness } \\
\cline { 2 - 12 } & -150 & -120 & -90 & -60 & -30 & 30 & 60 & 90 & 120 & 150 \\
\hline Gambar 1 & & & & & & & & & & \\
\hline Gambar 2 & & & & & & & & & & \\
\hline Gambar 3 & & & & & & & & & & \\
\hline Gambar 4 & & & & & & & & & & \\
\hline Gambar 5 & & & & & & & & & & \\
\hline \hline
\end{tabular}

berkas tidak kembali

berkas kembali namun tidak lengkap

Dari Tabel 4.1 dan Tabel 4.2. dapat disimpulkan bahwa perubahan tingkat kecerahan pada stego image yang dilakukan pada 5 gambar tersebut tidak semuanya dapat mengembalikan berkas yang disisipi sebelumnya, metode Dynamic Cell Spreading yang dapat mengembalikan berkas terdapat pada gambar pertama dengan perubahan brightness -30 dan 30 sedangkan metode Spread Spectrum yang dapat mengembalikan berkas pada gambar pertama dengan perubahan brightness -30,30 dan gambar ketiga dengan perubahan brightness -150,-90,-30 kata lain implementasi teknik steganografi menggunakan metode Dynamic Cell Spreading(DCS) dan Spread Spectrum ini tidak tahan terhadap perubahan tingkat kecerahan (brightness).

\subsubsection{Pengujian Perubahan Contrast}

Pada percobaan ini dilakukan dengan cara melakukan perubahan contrast dengan interval $-150,-120$, $-90,-60,-30,30,60,90,120,150$ di masing-masing citra stegoimage. Contoh manipulasi stegoimage dengan perubahan contrast disajikan pada Tabel 5.

Tabel 5. Perubahan Contrast

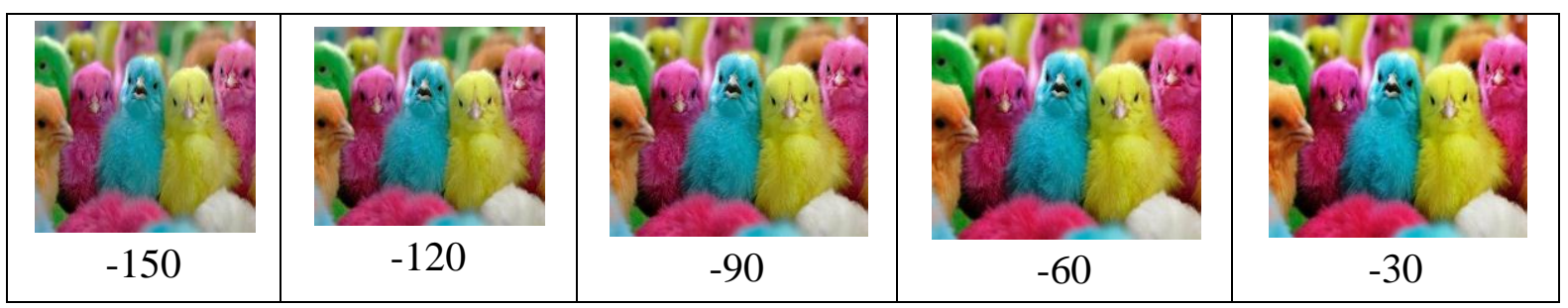




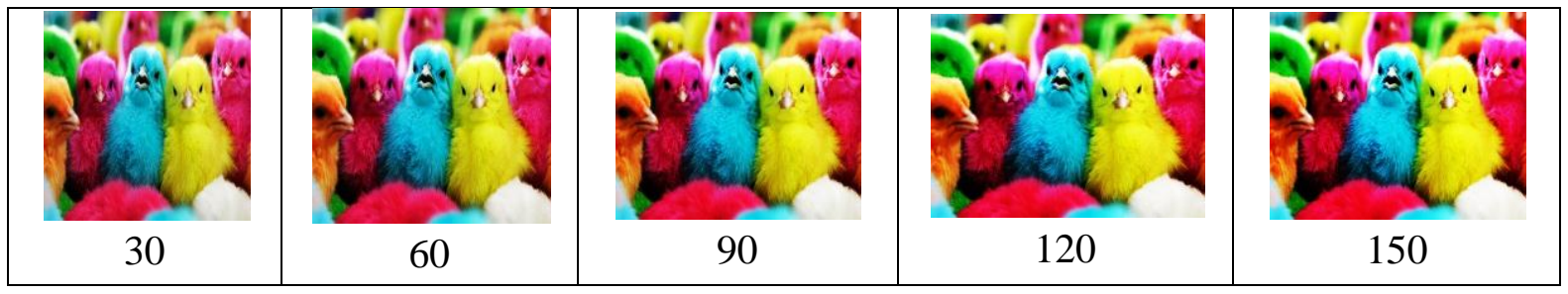

Setelah dilakukan perubahan contrast pada seluruh stegoimage dengan menggunakan metode Spread Spectrum dan Dynamic Cell Spreading (DCS), gambar yang tidak tahan terhadap perubahan contrast. Berikut ulasan pengujian dengan perubahan contrast dapat dilihat pada Tabel 6.1 dan Tabel 6.2

Tabel 6.1.Ulasan Pengujian Perubahan Contrast DCS

\begin{tabular}{|c|c|c|c|c|c|c|c|c|c|c|}
\hline \multirow{2}{*}{ No Gambar } & \multicolumn{7}{|c|}{ Perubahan Contrast } \\
\cline { 2 - 11 } & -150 & -120 & -90 & -60 & -30 & 30 & 60 & 90 & 120 & 150 \\
\hline Gambar 1 & & & & & & & & & & \\
\hline Gambar 2 & & & & & & & & & & \\
\hline Gambar 3 & & & & & & & & & & \\
\hline Gambar 4 & & & & & & & & & & \\
\hline Gambar 5 & & & & & & & & & \\
\hline \hline
\end{tabular}

Tabel 6.2. Ulasan Pengujian Perubahan Contrast Spread Spectrum

\begin{tabular}{|c|c|c|c|c|c|c|c|c|c|c|}
\hline \multirow{2}{*}{ No Gambar } & \multicolumn{7}{|c|}{ Perubahan Contrast } \\
\cline { 2 - 12 } & -150 & -120 & -90 & -60 & -30 & 30 & 60 & 90 & 120 & 150 \\
\hline Gambar 1 & & & & & & & & & & \\
\hline Gambar 2 & & & & & & & & & & \\
\hline Gambar 3 & & & & & & & & & & \\
\hline Gambar 4 & & & & & & & & & & \\
\hline Gambar 5 & & & & & & & & & \\
\hline
\end{tabular}

Dari Tabel 6.1 dan Tabel 6.2. dapat disimpulkan bahwa perubahan contrast pada stego image yang dilakukan pada 5 gambar tersebut tidak semuanya dapat mengembalikan berkas yang disisipi sebelumnya metode Dynamic Cell Spreading yang dapat mengembalikan berkas terdapat pada gambar pertama dengan perubahan contrast -150,-120,-90,-60,-30,30 sedangkan metode Spread Spectrum yang dapat mengembalikan berkas pada gambar pertama dengan perubahan contrast $-150,-120,-90,-60,-$ 30,30,60,90,120,150 dan gambar ketiga dengan perubahan contrast -150,-90,-60,-30,30,60,150 dengan kata lain implementasi teknik steganografi menggunakan metode Dynamic Cell Spreading (DCS) dan Spread Spectrum ini tidak tahan terhadap perubahan tingkat kecerahan (contrast). 


\subsubsection{Pengujian Pemotongan Gambar (Cropping)}

Pada pengujian ini dilakukan pemotongan gambar pada masing-masing stegoimage disetiap area kanan, kiri, atas, bawah dan seluruh. Contoh pemotongan gambar stegoimage disajikan pada Tabel 7.

Tabel 7. Pemotongan Gambar Stegoimage

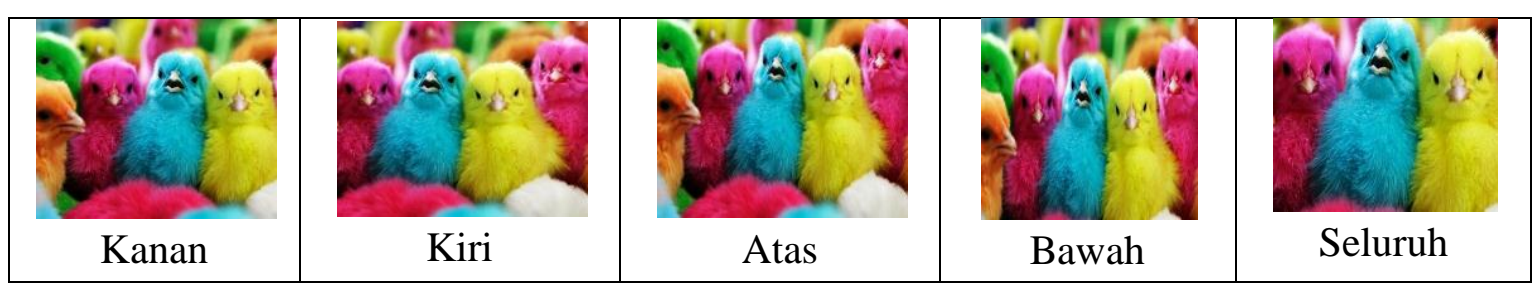

Setelah dilakukan perubahan crop pada seluruh stegoimage dengan menggunakan metode Spread Spectrum dan Dynamic Cell Spreading (DCS), gambar yang tidak tahan terhadap perubahan crop. Berikut ulasan pengujian dengan perubahan crop dapat dilihat pada Tabel 8.1 dan Tabel 8.2

Tabel 8.1. Ulasan Pengujian Pemotongan Gambar (Crop) DCS

\begin{tabular}{|l|l|l|l|l|l|}
\hline \multirow{2}{*}{ No Gambar } & \multicolumn{5}{|c|}{ Pemotongan Gambar (Crop) } \\
\cline { 2 - 6 } & Kanan & Kiri & Atas & Bawah & Seluruh \\
\hline Gambar 1 & & & & & \\
\hline Gambar 2 & & & & & \\
\hline Gambar 3 & & & & & \\
\hline Gambar 4 & & & & & \\
\hline Gambar 5 & & & & & \\
\hline \hline
\end{tabular}

berkas tidak kembali $\square$ berkas kembali namun tidak lengkap $\square$ berkas kembali utuh

Tabel 8.2. Ulasan Pengujian Pemotongan Gambar (Crop) Spread Spectrum

\begin{tabular}{|l|l|l|l|l|l|}
\hline \multirow{2}{*}{ No Gambar } & \multicolumn{5}{|c|}{ Pemotongan Gambar (Crop) } \\
\cline { 2 - 6 } & Kanan & Kiri & Atas & Bawah & Seluruh \\
\hline Gambar 1 & & & & & \\
\hline Gambar 2 & & & & & \\
\hline Gambar 3 & & & & & \\
\hline Gambar 4 & & & & & \\
\hline
\end{tabular}




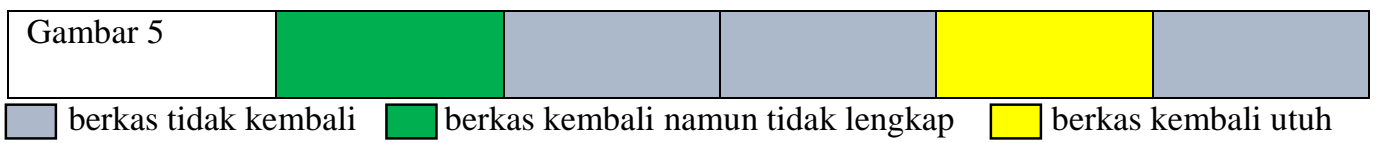

Dari Tabel 8.1. dan tabel 8.2 dapat disimpulkan bahwa pemotongan pada stego image yang dilakukan pada 5 gambar tersebut tidak semuanya dapat mengembalikan berkas yang disisipi sebelumnya. Pada metode Dynamic Cell Spreading dan Spread Spectrum, Stego Image yang berhasil mengembalikan berkas secara utuh terdapat pada gambar yang mengalami pemotongan di bagian bawah untuk Gambar 1,3,5. Pada metode Dynamic Cell Spreading untuk Gambar 1 dan Gambar 5 setelah dilakukan pemotongan di bagian kanan, berkas dapat dikembalikan namun tidak utuh atau terjadi kehilangan pada pesan di dalam berkas Sedangkan Spread Spectrum untuk Gambar 2,3,5 tetapi pada Gambar 5 setelah dilakukan pemotongan di bagian kanan dan bawah. Untuk Gambar 2 dan 3 setelah dilakukan pemotongan di bagian kanan. Dengan demikian implementasi teknik steganografi menggunakan metode Dynamic Cell Spreading(DCS) dan Spread Spectrum ini tidak tahan terhadap pemotongan gambar (stego image).

\section{Kesimpulan}

Kesimpulan yang dapat diambil dari penelitian ini adalah sebagai berikut :

1. Proses penyisipan pesan kedalam gambar terjadi dari kiri ke kanan pada bagian atas gambar, sehingga pemotongan stegoimage pada bagian kiri dan atas mempunyai resiko kehilangan data lebih besar, sebaliknya pemotongan pada bagian bawah dan kanan mempunya resiko yang kecil terjadinya kehilangan data tergantung ukuran gambar dan jumlah pixel.

2. Tidak terlihat perbedaan yang signifikan pada gambar karena penggunaan format file gambar (.jpg) sebagai input dan format file gambar (.png) sebagai output. Dengan demikian kedua format file tersebut baik digunakan untuk teknik steganografi.

3. Pada proses pemotongan gambar juga harus dilakukan pada bagian kanan gambar dan bagian bawah gambar untuk dapat mengembalikan tulisan pada berkas secara utuh, dengan catatan pemotongan gambar harus memperhitungkan ukuran gambar sehingga tulisan di dalam berkas yang disisipkan tidak terpotong dan dapat kembali secara utuh.

4. Pengujian manipulasi brightness, contrast, cropping dengan menggunakan metode Spread Spectrum lebih baik dalam hal ketahanan setelah dimanipulasi baik brightness, contrast, cropping.

5. Metode Spread Spectrum lebih baik, jika pihak lain tidak mengerti tentang teknik untuk melakukan steganalis.

6. Metode Dynamic Cell Spreading akan lebih baik digunakan jika pihak lain mengerti tentang steganografi karena pesan-pesan disisipkan dalam tiap pixel secara acak.

7. Pertambahan ukuran pada masing-masing metode tergantung kombinasi warna yang digunakan, gambar dengan dominan hitam akan memiliki ukuran gambar lebih besar sedangkan gambar dengan kombinasi warna dominan putih akan memiliki pertambahan ukuran gambar yang lebih sedikit karena tiap pixelnya didominasi nilai RGB yang lebih kecil.

\section{Referensi}

[1] Sellars, D. 2006.An Introduction to Steganography, ,http://www.cs.uct.ac.za/ courses/CS400W/NIS/papers99/dsellars/ stego.html, diakses tanggal 10 Februari 2015.

[2] Wijaya, Ermadi Satriya. dan Prayudi, Yudi. 2004.Konsep Hidden Message 
Menggunakan Teknik Steganografi Dynamic Cell Spreading. Jurnal Media Informatika, ISSN: 0854-4743, Volume 2, No. 1, PP 23-38.

[3] Vembrina, Yus Glas. 2006. Spread Spectrum Steganografi Program Studi Teknik Informatika Sekolah Teknik Elektro dan Informatika Institut Teknologi Bandung.

[4] Satzinger, John W. Robert Jackson. and Stephen D. Burd. 2010. Systems analysis and design in a changing world, Five Edition . Course Technology, Cengage Learning, Boston, Massachusetts. Canada. 